\title{
ANALISIS KOMODIFIKASI KONTRIBUTOR DALAM PRODUKSI BERITA TELEVISI
}

\author{
M. Gafar Yoedtadi ${ }^{1}$, Riris Loisa ${ }^{2}$, Genep Sukendro ${ }^{3}$, \\ Roswita Oktavianti ${ }^{4}$, Lusia Savitri Setyo Utami ${ }^{5}$ \\ ${ }^{1}$ Fakultas Ilmu Komunikasi, Universitas Tarumanagara Jakarta \\ Email: gafary@fikom.untar.ac.id \\ ${ }^{2}$ Fakultas Ilmu Komunikasi, Universitas Tarumanagara Jakarta \\ Email:ririsl@fikom.untar.ac.id \\ ${ }^{3}$ Fakultas Ilmu Komunikasi, Universitas Tarumanagara Jakarta \\ Email:geneps@fikom.untar.ac.id \\ ${ }^{4}$ Fakultas Ilmu Komunikasi, Universitas Tarumanagara Jakarta \\ Email: roswitao@fikom.untar.ac.id \\ ${ }^{5}$ Fakultas Ilmu Komunikasi, Universitas Tarumanagara Jakarta \\ Email:lusias@fikom.untar.ac.id
}

\begin{abstract}
The pattern of news production in the Indonesian television broadcasting industry generally uses two human resources, namely permanent journalists and temporary journalists. Regular journalists are organic employees of television companies. Meanwhile, journalists who are not permanent or contributors only work under a news sale and purchase contract. They are not the organic employees of the television company. They only get honorarium when the news airs. As a result of such a working relationship, the contributors' bargaining position is very weak in front of the television station management. The coverage and news agenda will follow the tastes of television stations. News coverage that is at risk of not airing will be avoided. As a result, there has been neglect of the ideal function of the media in serving the public interest. Based on the political economy theory of media, there has been a commodification of labor in the television news production process. The object of this research is the process of commodification of contributors in the production of television news.Meanwhile, the subjects of this study were television contributors, and news producers of Jakarta television stations.Other contributors who became research informants were in West Java and Ambon. This research uses a qualitative approach with a case study method. Collecting data using in-depth interviews, observation and literature study. The results showed that there has been a commodification of contributors in the production of television news. Television management exploits contributors. Television management promotes false consciousness among contributors who are unaware of the commodification.
\end{abstract}

Keywords: Commodification, contributor, television, political economy of communication

\section{ABSTRAK}

Pola produksi berita pada industri penyiaran televisi Indonesia umumnya memanfaatkan dua sumber daya manusia, yakni jurnalis tetap dan jurnalis lepas. Jurnalis tetap adalah karyawan organik dari perusahaan televisi. Sementara jurnalis lepas atau kontributor hanya bekerja berdasarkan kontrak jual beli berita. Mereka bukan karyawan organik perusahaan televisi. Mereka hanya mendapat imbalan honor ketika beritanya ditayangkan. Akibat dari hubungan kerja semacam itu, posisi tawar kontributor sangat lemah dihadapan manajemen stasiun televisi. Agenda peliputan dan berita akan mengikuti selera stasiun televisi. Peliputan berita yang berisiko tidak tayang akan dihindari. Akibatnya terjadi pengabaian fungsi ideal media dalam melayani kepentingan publik. Makalah ini hendak membedah proses komodifikasi kontributor berdasarkan teori ekonomi politik media. Penelitian ini menggunakan pendekatan kualitatif dengan metode studi kasus. Objek dari penelitian ini adalah proses komodifikasi kontributor dalam produksi berita televisi. Sementara itu subjek dari penelitian ini adalah para kontributor televisi, dan para produser berita stasiun televisi Jakarta. Kontributor lain yang menjadi informan penelitian berada di wilayah Jawa Barat dan Ambon. Pengumpulan data dengan menggunakan wawancara mendalam, observasi dan studi literatur. Hasil penelitian menunjukkan telah terjadi komodifikasi kontributor dalam produksi berita televisi. Manajemen televisi melakukan eksploitasi tenaga kontributor. Manajemen televisi mempromosikan kesadaran palsu kepada para kontributor sehingga tidak menyadari adanya komodifikasi tersebut.

Kata Kunci: Komodifikasi, kontributor, televisi, ekonomi politik komunikasi 


\section{PENDAHULUAN}

\section{Latar Belakang}

Industri penyiaran televisi hingga kini masih menjadi bisnis yang menguntungkan. Terbukti mampu meraih belanja iklan terbesar pada 2019. Menurut Lembaga Survei Nielsen, belanja iklan seluruh media di Indonesia pada 2019 mencapai Rp 168 triliun. Industri penyiaran televisi mendominasi 85 persen porsi iklan atau Rp 143 triliun. Jumlah tersebut tumbuh 14 persen dibanding tahun 2018 (Nielsen, 2020).

Industri penyiaran televisi tidak bisa dilepaskan dari iklan. Pendapatan industri penyiaran televisi nyaris seluruhnya dihasilkan dari pemasang iklan. Sukses komersial sebuah acara televisi tidak hanya ditentukan pada popularitasnya, tapi seberapa banyak acara tersebut mendapatkan pengiklan (Armando, 2016). Semakin banyak iklan, semakin besar keuntungan yang didapat. Bisnis penyiaran televisi membutuhkan investasi dan pembiayaan yang relatif tinggi dibandingkan jenis media lain. Maka orientasi dalam mencari keuntungan sangat dominan dalam bisnis penyiaran televisi (Blumenthal \& Goodenough, 2006). Dalam rangka memaksimalkan keuntungan tersebut, industri penyiaran televisi melakukan berbagai bentuk efisiensi. Salah satunya melakukan penghematan dari sisi sumber daya manusia. Pada produksi program berita contohnya, manajemen televisi memanfaatkan sumber daya manusia semurah mungkin. Yakni dengan membatasi jumlah jurnalis yang menjadi karyawan tetap. Penelitian Lestari, Suherdiana dan Muhaemin (2018) pada empat stasiun televisi di bawah bendera Grup MNC, yakni iNews, RCTI, MNC dan GTV memperlihatkan bahwa dalam proses penyatuan redaksi, jumlah jurnalis tetap yang bekerja di empat stasiun televisi tersebut diupayakan tidak terlampau besar. Sementara untuk peliputan di daerah, stasiun televisi Grup MNC menggunakan kontributor (Lestari, Suherdiana, \& Muhaemin, 2018).

Model kerja di televisi Grup MNC lazim pula dipraktikkan di stasiun televisi lain. Dalam struktur pekerja televisi dikenali dua model jurnalis, yaitu jurnalis tetap dan jurnalis lepas. Jurnalis tetap adalah para jurnalis yang menjadi karyawan organik dari stasiun televisi tempatnya bekerja. Sementara jurnalis lepas adalah para kontributor televisi yang bekerja hanya diikat dengan kontrak jual beli berita (istilah yang sering dipakai kontrak kemitraan). Mereka bukan karyawan organik stasiun televisi. Hubungan kerja mereka hanyalah menjual berita hasil liputan mereka secara tetap kepada stasiun televisi yang menyelenggarakan kontrak tersebut. Misalnya, stasiun televisi X memiliki kontributor di wilayah kota Ambon. Maka sang kontributor tersebut berkewajiban meliput berbagai peristiwa yang terjadi di kota Ambon, dan mengirimkan beritanya ke stasiun televisi X. Kontributor Ambon tersebut akan menerima honor jika beritanya tayang di stasiun televisi X. Peran kontributor tersebut hampir sama dengan seorang freelance. Hanya berbeda dengan freelance yang dapat menjual beritanya ke berbagai stasiun televisi, seorang kontributor terikat kontrak mitra hanya pada satu stasiun televisi (Santoso \& Lestari, 2017).

Implikasi dari hubungan kerja semacam ini adalah lemahnya posisi tawar kontributor terhadap stasiun televisi. Kontributor diwajibkan menjaga wilayah peliputannya 24 jam tujuh hari sepekan, meliput setiap peristiwa penting di wilayah liputannya, namun hanya akan dibayar jika beritanya ditayangkan. Tidak ada jaminan kesejahteraan lain, jenjang karir, atau penghargaan prestasi kerja. Celakanya, akibat dari situasi ini, agenda peliputan dan berita yang dihasilkan akan banyak ditentukan oleh pembeli, yakni stasiun televisi yang mengontrak para kontributor tersebut. Kreativitas untuk membuat liputan di luar "selera" redaksi stasiun televisi, jarang dilakukan karena berisiko beritanya tidak ditayangkan (Yoedtadi, Loisa, Sukendro, Oktavianti, \& Savitri, 2020). Sebaliknya jenis, topik berita yang disukai oleh redaksi stasiun televisi, akan berulang kali diliput karena berpotensi ditayangkan. Misalnya, berita jenis kriminal. Berita kriminal, terutama yang 
menghadirkan sensasi dan kesan vulgar, rata-rata mendapatkan rating yang tinggi (Lukitawati, 2019).

Akibat lebih jauh dari situasi ini adalah pengabaian peliputan peristiwa yang tidak mengandung nilai-nilai komersial (menghasilkan rating tinggi) oleh para kontributor. Karena posisi kontributor adalah penjual dan manajemen televisi adalah pembeli, tentunya keinginan pembeli yang akan didahulukan. Dalam perspektif kritis, pengabaian tersebut menyebabkan industri penyiaran televisi tidak dapat diharapkan menjalankan peran ideal jurnalisme, yakni sebagai sarana penyebar informasi, membantu menafsirkan peristiwa yang terjadi di lingkungannya, membangun opini publik, merekatkan masyarakat, mendidik, mensosialisasikan nilai-nilai, sekaligus memberi hiburan (Armando, 2016).

Ada dua hal yang patut dicatat dari fenomena jurnalis lepas atau kontributor. Pertama hubungan yang timpang antara manajemen televisi Jakarta dengan kontributor merupakan pola komodifikasi tenaga kerja yang dilakukan oleh manajemen televisi dalam rangka penghematan biaya produksi. Kedua, komodifikasi tenaga kerja tersebut menyebabkan berkurangnya fungsi ideal media dalam melayani publik.

Komodifikasi adalah konsep dikemukakan oleh Mosco (2009) untuk mendefinisikan proses mengubah barang dan jasa, termasuk komunikasi, yang dinilai karena kegunaannya, menjadi komoditas yang dinilai karena apa yang akan mereka berikan di pasar. Adam Smith dan teori ekonomi politik klasik (dalam Mosco, 2009) membedakan antara produk yang nilainya muncul dari pemuasan keinginan dan kebutuhan khusus manusia, disebut sebagai nilai guna (use value), dan produk yang nilainya didasarkan atas apa yang bisa ia berikan dalam pertukaran, disebut nilai tukar (exchange value). Sedangkan komoditas adalah bentuk tertentu dari produk ketika produksinya terutama diorganisasikan melalui proses pertukaran. Komodifikasi adalah proses perubahan nilai guna menjadi nilai tukar. Dalam kata-kata Mosco (2009):

"Commodification is the process of transforming things valued for their use into marketable products that are valued for what they can bring in exchange. Adam Smith and classical political economy distinguished between products whose value derives from satisfaction of specific human want or need, i.e. use value, and those whose value is based on what the product can command in exchange, i.e. exchange value. The commodity is the particular form that products take when their production is principally organized through the process of exchanges. Commodification is the process of transforming use values into exchanges values."

Konsep komodifikasi merupakan bagian penting dari teori ekonomi politik media. Ekonomi politik media menjelaskan sistem kapitalis media massa yang menginginkan keuntungan ekonomi dan politik. Untuk mencapai tujuan tersebut umumnya industri media melakukan praktik-praktik komodifikasi dalam proses produksinya (Putri \& Endang, 2018). Komodifikasi juga merupakan pintu masuk untuk memahami praktik-praktik institusi komunikasi yang spesifik. Antara lain, peningkatan komersialisasi media, privatisasi institusi komunikasi dan media publik, dan liberalisasi pasar komunikasi (Ibrahim \& Akhmad, 2014).

Berdasarkan tinjauan pustaka yang dilakukan oleh peneliti, belum ada kajian yang secara khusus meneliti proses komodifikasi kontributor dalam produksi berita televisi. Namun demikian terdapat beberapa kajian yang memiliki kesamaan dalam hal komodifikasi pekerja televisi. Penelitian pertama oleh Ahmad Budiman Sudarsono (2018) berjudul "Komodifikasi Pekerja Media Dalam Industri Hiburan Televisi" mengungkap tentang proses komodifikasi presenter televisi Ananda 
Omesh yang membawakan acara kuis Family 100. Hasil penelitian tersebut menyimpulkan telah terjadi komodifikasi pekerja media terhadap Ananda Omesh melalui tiga tahap: separate, concentrate dan reconstitute.

Kajian lain yang meneliti mengenai komodifikasi pekerja media televisi dilakukan oleh Sidy Amalia Putri, Anis Endang, Fera Indah Sari (2018). Penelitian yang mengambil judul "Komodifikasi Pekerja di Lembaga Penyiaran Publik TVRI Bengkulu", menyimpulkan bahwa telah terjadi komodifikasi pekerja di TVRI Bengkulu terutama tenaga freelance. Hal ini terlihat dari beban kerja tenaga freelance yang tidak seimbang dengan hasil yang mereka dapatkan, uang gaji yang tidak sesuai, tidak mendapatkan uang lembur, tidak ada hari libur yang pasti, tidak mendapatkan kenaikan gaji atau penghargaan bila menghasilkan prestasi dalam bekerja, hingga aksi protes yang tidak pernah ditanggapi.

Kajian lain yang berhubungan dengan komodifikasi pekerja televisi adalah "Legalitas Stringer dan Karya Jurnalistik dalam Media Televisi", oleh Didik Haryadi Santoso dan Rani Dwi Lestari (2017). Penelitian tersebut tidak mendalami proses komodifikasi pekerja, namun mempersoalkan legalitas stringer dalam kerja jurnalistik televisi. Penelitian tersebut menyimpulkan stringer dalam industri media televisi menjadi praktik simbiosis mutualisme antara stringer, kontributor di daerah dan perusahaan media. Praktik stringer dinilai tidak legal sebab berada pada ketidakjelasan hak serta kewajibannya sebagai pekerja media yang resmi. Secara legalitas karya video jurnalistik yang dihasilkan oleh stringer termasuk illegal meskipun diklaim sebagai karya jurnalis resmi. Hal ini melanggar kode etik jurnalistik sebab pemberitaan hasil karya yang telah dimuat di media pada dasarnya dilindungi sebagai hasil karya cipta dan masuk dalam kategori intellectual property right.

\section{Rumusan Masalah}

Berdasarkan latar belakang masalah di atas, artikel ini memiliki rumusan masalah bagaimanakah proses komodifikasi kontributor dalam produksi berita televisi?

\section{METODE PENELITIAN}

\section{Kualitatif Studi Kasus}

Penelitian pada makalah ini menggunakan pendekatan kualitatif dengan metode studi kasus. Moleong (2009) mengatakan penelitian kualitatif adalah penelitian yang bermaksud untuk memahami fenomena tentang apa yang dialami subjek penelitian, misalnya perilaku, persepsi, motivasi, tindakan secara holistik dan dengan cara deskripsi dalam bentuk kata-kata dan bahasa pada suatu konteks khusus yang alamiah dan dengan memanfaatkan metode ilmiah. Creswell (2002) mengatakan penelitian studi kasus dimana peneliti menggali kesatuan atau fenomena tunggal (kasus) yang dibatasi oleh waktu dan aktivitas (program, kejadian, proses, institusi, atau kelompok sosial) dan mengumpulkan informasi rinci dengan menggunakan berbagai prosedur pengumpulan data selama periode waktu yang lama. Penelitian ini menggunakan studi kasus tunggal untuk menelaah proses komodifikasi kontributor dalam produksi pemberitaan televisi.

\section{Objek dan Subjek Penelitian}

Objek dari penelitian ini adalah proses komodifikasi kontributor dalam produksi berita televisi. Subjek dari penelitian ini adalah para kontributor televisi, dan para produser berita stasiun televisi Jakarta. Kontributor yang menjadi informan penelitian berada di wilayah Jawa Barat dan Ambon.

\section{Teknik Pengumpulan Data}

Teknik pengumpulan data dalam penelitian ini dilakukan dengan menggunakan wawancara mendalam terhadap para informan penelitian, yakni kontributor dan produser pemberitaan televisi. 
Dalam penelitian kualitatif pada umumnya wawancara tidak dilakukan secara terstruktur ketat. Wawancara dilakukan dengan pertanyaan yang mengarah pada kedalaman informasi serta dilakukan dengan cara tidak formal terstruktur. Wawancara mendalam dapat dilakukan pada waktu dan kondisi konteks yang dianggap paling tepat guna mendapat data yang rinci, jujur dan mendalam (Kriyantono, 2020). Selain wawancara mendalam, peneliti juga melakukan observasi tidak berperan serta dan studi literatur untuk melengkapi data penelitian. Data-data yang didapatkan dari hasil penelitian kemudian didiskusikan dalam FGD dengan peserta Dewan Pers, Ikatan Jurnalis Televisi Indonesia (IJTI) dan produser pemberitaan televisi Jakarta pada 26 Agustus 2020.

\section{Analisa Data dan Triangulasi}

Teknik analisis data yang digunakan dalam penelitian ini adalah teknik analisis data model Miles, Huberman dan Saldana (Kriyantono, 2020). Menurut Miles, Huberman dan Saldana, teknik analisis ini pada dasarnya terdiri dari empat tahapan, yaitu pengumpulan data, kondensasi data, penyajian data dan penarikan kesimpulan. Data-data hasil wawancara dengan para informan berupa rekaman wawancara terlebih dulu akan dipindahkan dalam bentuk naskah transkrip wawancara dalam paragraf utuh. Peneliti dalam hal ini tidak melakukan reduksi data, sehingga pandangan-pandangan informan yang berlawanan dengan beberapa informan lain tetap ditampilkan untuk didialogkan. Kemudian data tersebut dianalisis dan dikelompokkan (coding) ke dalam pokok-pokok pikiran, dikembangkan dalam tema dan dibuat kategori-kategori. Selanjutnya dilakukan sintesis atas data-data hasil analisis sehingga dapat dihasilkan sebuah kesimpulan.

Triangulasi adalah teknik pemeriksaan keabsahan data yang memanfaatkan sumber yang lain (Moleong, 2009). Teknik triangulasi dalam penelitian ini memanfaatkan peneliti atau pengamat lainnya untuk keperluan pengecekan kembali derajat kepercayaan data.

\section{HASIL DAN PEMBAHASAN}

\section{Hasil}

Kehadiran kontributor pada industri penyiaran televisi, boleh jadi disebabkan oleh kegagalan pemerintah membangun sistem siaran jaringan (SSJ) di Indonesia. Akibatnya penyiaran televisi Indonesia didominasi oleh stasiun televisi Jakarta. Untuk menjangkau siaran ke wilayah lain, stasiun televisi Jakarta umumnya hanya membangun stasiun transmisi untuk memancar ulang program-programnya. Dengan model penyiaran terpusat tersebut, televisi Jakarta dapat berhemat miliaran rupiah karena tidak perlu membangun stasiun televisi lokal atau bekerja sama dengan stasiun televisi lokal membentuk jaringan (Armando, 2011).

Di samping penghematan dari segi biaya infrastruktur, biaya sumber daya manusia pun dapat dihemat karena tidak perlu merekrut karyawan tetap di daerah. Untuk memperluas jangkauan peliputan di wilayah lain, manajemen televisi Jakarta tidak membangun kantor cabang atau biro daerah. Mereka cukup merekrut kontributor sebagai jurnalis lepas. Biasanya kontributor berdomisili di ibu kota provinsi atau kota kabupaten. Mereka memiliki wilayah peliputan sesuai pembagian yang sudah diatur oleh manajemen televisi Jakarta. Dalam satu provinsi, biasanya terdapat lebih dari satu orang kontributor. Jumlah kontributor bergantung dari potensi berita di wilayah tersebut. Sejauh ini jumlah kontributor lebih banyak di pulau Jawa. Penyebabnya adalah penonton televisi di pulau Jawa lebih dominan, daripada di luar pulau Jawa.

Hubungan kerja kontributor dengan manajemen televisi adalah kontrak jual beli berita yang diperbarui dalam jangka waktu tertentu (biasanya setahun). Memang terdapat stasiun televisi yang menempatkan kontributor sebagai karyawan tetap, namun hal itu tidak lazim dilakukan di televisi 
pada umumnya. Menurut informan penelitian, sebagian besar legalitas kontributor hanya kontrak jual beli berita. Honor berita tayang berbeda-beda pada setiap stasiun televisi. Rata-rata berkisar Rp 300 ribu hingga Rp 400 ribu per berita tayang. Salah seorang informan penelitian mengakui bahwa tarif Rp 300 ribu per berita tayang tersebut belum pernah berubah sejak 17 tahun yang lalu. Celakanya, tarif yang tak berubah ini kerap kali juga tak terbayar akibat problem administrasi di Jakarta. Terutama untuk pembayaran honor tambahan jika berita kontributor digunakan juga di media yang lain. Contohnya dipublikasikan di media daring yang masih di bawah satu payung grup usaha. Menghadapi hal ini, biasanya kontributor bersikap pasrah.

"Dulu ada perjanjian, jadi kita yang tayang di liputan6.com juga dibayar, tapi sekarang banyak, saya dan temen-temen juga, saya gak pernah ngeklaim itu, tapi temen-temen masih ada yang klaim, karena harus klaim dulu tonton dulu, masuk ga? Baru di klaim. Karena mungkin kalau untuk sekarang, gimana yah, saya sudah 11 tahun kerja seperti ini mungkin agak sedikit ilmu juga yah, kalau untuk klaim apa, klaim apa ah ribet, uangnya ga seberapa, ah cape lah, biarin lah gitu yang penting kita aman kirim aja lah gitu." (Informan Kontributor wawancara 24 Agustus 2019)

Jika materi beritanya digunakan di stasiun televisi lain atau media yang masih dalam satu grup usaha, ada yang memberikan tambahan uang, namun ada yang tidak karena menganggap berita tersebut sudah menjadi milik mereka dan dapat digunakan secara bebas. Seperti diketahui sebagian besar stasiun televisi di Jakarta telah membentuk grup usaha di bawah satu kepemilikan. Bukan hal aneh jika dikatakan usaha penyiaran televisi di Indonesia menjalankan praktik kapitalisme dengan melakukan pemusatan dan konsentrasi modal dengan tujuan efisiensi dan memenangkan kompetisi. Tercatat terdapat grup usaha MNC (iNews, RCTI, GTV, MNC), SCM (SCTV \& Indosiar), Trans Media (Trans TV \& Trans 7), Viva Media (TV One \& AN TV) (Yoedtadi \& Hapsari, 2020).

Setiap kontributor dibekali seragam dan kartu identitas oleh manajemen televisi Jakarta. Hal ini untuk menunjukkan bahwa mereka adalah perwakilan resmi televisi di wilayah tersebut. Seragam dan kartu identitas memudahkan mereka dalam melakukan peliputan karena keberadaannya jelas di mata narasumber. Dengan seragam dan kartu identitas mereka akan diterima oleh narasumber dan dapat membina hubungan baik dengan para pejabat setempat. Mereka terhindar dari tuduhan sebagai jurnalis "abal-abal”.

Setiap kontributor harus memiliki keterampilan yang serba bisa, dari mengoperasikan kamera, menulis naskah, hingga menyunting gambar. Manajemen televisi secara berkala memberikan pelatihan kepada kontributor untuk meningkatkan keterampilan jurnalistik. Manajemen televisi menyelenggarakan pelatihan secara bergilir di beberapa daerah. Tetapi lebih sering kontributor meningkatkan keterampilannya dengan belajar secara mandiri.

Peralatan produksi seperti kamera, tripod, lampu, microphone hingga komputer laptop untuk menyunting gambar disiapkan sendiri oleh kontributor. Sekali waktu ada program kredit kamera ditawarkan oleh manajemen televisi di Jakarta. Mekanisme pelunasan dengan cicilan potong honor per bulan. Namun program kredit kamera tidak selalu ada di setiap stasiun televisi. Tergantung kebijakan masing-masing stasiun televisi. Selain itu tidak setiap kontributor diberikan peluang untuk ikut program kredit kamera. Kontributor yang honornya rata-rata per bulan tidak mencapai jumlah cicilan kamera tidak akan diikutkan dalam program kredit tersebut. 
Dari sisi kesejahteraan para kontributor mengalami nasib yang berbeda-beda. Ada kontributor "kaya", dan ada yang "miskin". Jika kontributor berada di wilayah dimana beritanya sering dibeli karena sesuai "selera" Jakarta, maka penghasilannya bisa di atas rata-rata UMP setempat. Bahkan jumlahnya bisa berkali-kali lipat. Salah seorang informan yang berdomisili di wilayah "kaya" berita (Jawa Barat), mengaku mampu mengirim 40 - 60 item berita dalam sebulan ke Jakarta. Sebaliknya jika kontributor berada di wilayah yang "kering" berita, maka honor yang didapat sangat kecil dibanding UMP setempat. Bahkan dalam sebulan belum tentu mereka mendapat honor. Padahal untuk melakukan peliputan, para kontributor telah mengeluarkan biaya terlebih dulu. Lantas bagaimanakah mereka membiayai kebutuhan hidupnya? Rata-rata kontributor memiliki penghasilan sampingan di luar pekerjaan jurnalistik. Antara lain berdagang atau memiliki "usaha".

"Jadi kita haruslah berpandai-pandai mencari peluang. Karena saya berfikir begini sebagai masukan, saya dulu berfikir saya menjadi ekor tapi ekor di gajah, mendingan saya menjadi kepala tapi di semut, perusahaan SCTV besar kan tapi di ekor, tapi kalau saya berfikir bagaimana ini saya bisa memberikan kesajahteraan buat orang lain tapi gimana saya juga sejahtera." (Informan Kontributor wawancara 24 September 2019)

Kondisi ketidakpastian jumlah honor tersebut diperburuk dengan kompetisi antar kontributor dalam menjual berita. Durasi program berita televisi jenis hiburan terbatas, berkisar tiga hingga empat jam sehari. Sudah tentu tak mampu menampung seluruh kiriman berita dari para kontributor. Seleksi berita harus dilakukan untuk menjaga rating dan share program. Tidak semua berita kontributor dapat ditayangkan. Apalagi jika ada peristiwa penting dan berskala nasional terjadi di Jakarta, praktis seluruh durasi pemberitaan akan terfokus di Jakarta. Alasan lain adalah persoalan bisnis. Penonton televisi lebih banyak di Jakarta, sehingga berita Jakarta lebih dominan.

"Nah, kenapa Jakarta banyak, ya kalau kita lebih ke realistik, kalau bisa diterjemahkan bisnis ya bisnis, rating ya rating, dalam artian bagaimana pun penonton, karena kami $T V$, sementara yang dipercaya oleh klien pengiklan itu adalah..., penonton Jakarta itu lebih dari 60\% ya, 64 persen. Artinya apa? Artinya, kita ya kalau dengan ilmu jurnalistik, proximity segala macem, itu kenapa kok Jakarta lebih banyak." (Informan Produser TV Jakarta wawancara 25 Agustus 2020)

Luas wilayah peliputan kontributor seringkali menjadi masalah. Informan penelitian mengakui wilayah peliputannya terlampau luas untuk dipantau sendirian. Satu wilayah provinsi hanya dijaga oleh satu orang kontributor. Bisa juga tiga atau empat kabupaten dipantau oleh satu kontributor. Akibatnya kontributor terpaksa pontang-panting mengejar peristiwa yang terjadi di wilayah peliputannya. Tidak jarang mereka harus berdebat panjang dengan manajemen televisi karena diminta untuk mengirimkan berita di lokasi liputan yang jauh.

"Saya sih sering kayak gitu. Itu karena kebutuhan redaksi juga sih mereka kadang minta, karena kita program newsnya banyak jadi dikejar terus. 'Bang, ini ada kejadian di sini. Boleh minta?' Kayak tadi lagi ya. 'Belajar geografinya dulu bang. Buka petanya bang'. Biar malam 'Bang kita butuh visualnya' wah ini Maluku, dari Ambon jauh. Kebanyakannya mereka lihat di Facebook, cari-cari, nah kan ada yang posting-posting. Karena jauh. Sinyalnya disana juga gak ada. Kebanyakannya kayak gitu. Mereka karena butuh cepat update-nya mau ini. "Bang nih ada ini. Minta dong gambarnya”. Waduh bagaimana kita mau pergi." (Informan Kontributor wawancara 8 Juli 2019) 
Untuk menyiasati luasnya wilayah peliputan, kontributor umumnya mempekerjakan asisten atau pembantu yang disebut stringer. Mereka ditempatkan di lokasi-lokasi yang berjarak jauh dari domisili kontributor. Stringer merupakan perpanjangan tangan kontributor di lokasi tersebut. Keberadaan mereka tidak diakui oleh manajemen televisi, meski beritanya dinikmati oleh stasiun televisi. Jika beritanya tayang, maka nama kontributor yang ditampilkan. Mereka dijuluki "tuyulnya kontributor". Stringer menjadi tanggung jawab kontributor. Mereka mendapat honor dari kontributor. Sangat disayangkan praktik memelihara stringer karena melanggar aturan ketenagakerjaan dan kode etik jurnalistik (Santoso \& Lestari, 2017).

\section{Pembahasan}

Komodifikasi adalah konsep dalam teori ekonomi politik media untuk menggambarkan bekerjanya sistem kapitalis di ranah komunikasi. Menurut McQuail (Ibrahim \& Akhmad, 2014) teori ekonomi politik media adalah pendekatan kritik sosial yang memfokuskan pada hubungan antara struktur ekonomi dan dinamika industri media serta konten ideologi media. Sudut pandang teori ekonomi politik meletakkan media sebagai bagian dari sistem ekonomi dalam hubungan erat dengan sistem politik. Sebagai konsekuensi antara lain berkurangnya media yang independen, konsentrasi pada khalayak yang lebih besar, mengurangi resiko, hilangnya tugas media yang kurang menguntungkan, dan pengabaian pada khalayak yang lebih kecil dan miskin.

Komodifikasi, menurut Mosco (2009) adalah proses mengubah barang atau jasa, termasuk komunikasi, yang dinilai karena kegunaannya, menjadi komoditas yang dinilai karena apa yang akan mereka berikan di pasar. Secara singkat komodifikasi adalah proses mengubah nilai guna menjadi nilai tukar. Dalam konteks komunikasi, fungsi media sebelumnya hanya dihadirkan untuk memenuhi kegunaannya (informasi, pendidikan, sosialisasi, hiburan), kemudian diubah/dikemas agar memiliki nilai yang mendatangkan keuntungan pasar (nilai-nilai komersial).

Mosco (2009) membagi komodifikasi ke dalam tiga bentuk, yakni komodifikasi isi (content), komodifikasi khalayak (audiens) dan komodifikasi pekerja (labor). Bentuk pertama adalah komodifikasi isi media. Proses komodifikasi ini dimulai ketika pekerja media mengubah pesan melalui teknologi yang ada menuju sistem interpretasi yang penuh makna sehingga menjadi pesan yang laku dijual.

Sementara komodifikasi khalayak terjadi karena khalayak merupakan komoditi penting untuk media media massa dalam mendapatkan iklan. Media dapat menciptakan khalayaknya sendiri dengan membuat program semenarik mungkin dan kemudian khalayak tersebut ditawarkan kepada para pengiklan. Singkatnya media menjual khalayak dalam bentuk ukuran rating atau share kepada pengiklan agar membeli slot waktu (airtime) televisi mereka. Khalayak merupakan faktor penting bagi media, karena jumlah khalayak akan menjadi daya tarik bagi pemasang iklan atau sponsor (Doyle, 2006).

Berikutnya adalah komodifikasi pekerja. Pekerja merupakan penggerak kegiatan produksi media. Tenaga dan kreativitas pekerja dimanfaatkan pemilik media untuk menghasilkan isi media. Dalam pandangan Marx, para kapitalis pemilik modal melakukan eksploitasi tenaga kerja untuk menghasilkan nilai lebih (surplus value) dalam rangka ekspansi modal. Tenaga kerja ditempatkan menjadi komoditas atau faktor produksi, sama halnya dengan tanah dan bahan mentah. Pekerja dipaksa menukar tenaga kerjanya dengan upah yang tidak memberikan kompensasi penuh atas tenaga yang mereka jual. Komodifikasi tenaga kerja direproduksi melalui proses eksploitasi absolut (memperpanjang hari kerja) dan eksploitasi relatif (intensifikasi proses kerja) yang memperdalam ekstraksi dari nilai lebih (Mosco, 2009). Terjadilah eksploitasi dalam 
memanfaatkan tenaga kerja media. Studi yang dilakukan oleh Aliansi Jurnalis Independen (AJI) pada 2019 menunjukkan, dari 31 media di Indonesia, hanya satu media yang dinilai memberi upah layak untuk jurnalis (Duilah, 2019).

Pemanfaatan tenaga dan pikiran pekerja secara optimal dilakukan pemilik modal dengan cara mengonstruksi pemikiran bahwa betapa menyenangkan bekerja dalam sebuah institusi media massa, walaupun dengan upah yang terkadang tak layak. Jika mengambil asumsi Marx mengenai kesadaran palsu (false consciousness), maka pemilik media mempromosikan kesadaran palsu kepada para pekerja. Kesadaran palsu terjadi ketika pekerja tidak menyadari bahwa mereka sesungguhnya tak lebih daripada seorang buruh atau alat produksi semata. Ketika menjalankan otonominya, seorang pekerja media merasa seolah-olah menjadi seorang borjuis media (McQuails, 2011).

Pemanfaatan kontributor oleh manajemen stasiun televisi dapat dimasukkan sebagai komodifikasi tenaga kerja media. Terjadi eksploitasi oleh manajemen televisi terhadap kontributor. Mereka dipekerjakan sebagai tulang punggung peliputan berita di daerah, tanpa mendapat kompensasi yang pantas. Legalitas hubungan kerja hanya diikat dengan kontrak jual beli berita yang akan dievaluasi tiap tahun. Dengan status bukan karyawan, mereka tidak mendapat jaminan kesejahteraan yang layak, mereka tidak memiliki jenjang karir dan masa depan yang jelas. Manajemen televisi sengaja menggunakan sistem kontributor untuk memperbesar keuntungan usaha. Dalam pemikiran Marx, total output berupa program televisi harus mampu dijual sebesar mungkin untuk menutup total investasi yang ditekan semurah mungkin sehingga tercapai nilai lebih (surplus value) (Mosco, 2009).

Proses komodifikasi tenaga kerja dimulai dengan melakukan rekrutmen kotributor yang layak untuk dipekerjakan. Kemudian manajemen televisi memberikan pelatihan dalam rangka meningkatkan kemampuan kontributor. Manajemen televisi juga membantu memberikan fasilitas kredit kamera agar peralatan liputan memenuhi standar televisi. Selanjutnya manajemen televisi memberikan seragam dan kartu identitas, untuk membantu kontributor ketika meliput. Seragam dan kartu identitas memberi keleluasaan kepada kontributor untuk menemui narasumbernarasumber resmi. Inilah tahapan-tahapan yang sesuai dengan asumsi Marx, bahwa dari sudut pandang modal, para kapitalis memulai proses produksi dengan membeli tenaga kerja (labor power) dan alat-alat produksi (means of production) (Mosco, 2009).

Para kapitalis selanjutnya membangun sistem produksi absolut, dan menutup peluang adanya sistem produksi di luar dirinya. Tenaga kerja tidak memiliki pilihan lain kecuali mengikuti sistem produksi tersebut (Mosco, 2009). Dalam konteks produksi berita televisi, kontributor tidak memiliki pilihan lain, kecuali bekerja dalam sistem tersebut. Hampir semua stasiun televisi Jakarta menggunakan sistem kerja kontributor yang sama. Pendek kata kontributor bisa saja pindah kerja dari satu stasiun televisi ke televisi yang lain, namun tetap menemui sistem kontrak yang sama. Hal ini tergambar dari honor tayang berita yang tidak terpaut jauh di antara stasiun televisi (berkisar Rp 300 ribu - Rp 400 ribu). Lebih parah lagi honor tersebut selama 17 tahun tak pernah mengalami kenaikkan. Selain itu kontributor tidak memiliki kebebasan menjual karya jurnalistiknya ke televisi lain karena terikat kontrak mitra eksklusif pada satu manajemen televisi.

Berbagai fasilitas (kredit kamera, seragam, kartu identitas) yang diberikan manajemen televisi tanpa disadari oleh kontributor adalah bagian dari langkah eksploitasi tenaga kerja. Sebagai gantinya, para kontributor harus siap 24 jam tujuh hari sepekan menjaga wilayah peliputan yang telah diamanatkan manajemen televisi. Mereka harus siap memenuhi permintaan dari Jakarta. 
Tidak boleh ada peristiwa penting yang lolos tidak diberitakan, karena hal itu akan mempengaruhi penilaian kinerja mereka. Dalam terminologi Mosco (2009) telah terjadi eksploitasi absolut (memperpanjang hari kerja) dan eksploitasi relatif (intensifikasi proses kerja). Eksploitasi semacam ini pada akhirnya menciptakan eksploitasi baru berupa penggunaan stringer oleh kontributor (Santoso \& Lestari, 2017).

Para kontributor tidak menyadari bahwa telah terjadi komodifikasi terhadap dirinya. Tidak ada penolakan dan protes dari kontributor. Kalaupun ada lebih bersifat individu dan tidak esensial. Hal ini dimungkinkan karena manajemen televisi mempromosikan kesadaran palsu kepada mereka. Antara lain dengan memberikan seragam dan kartu identitas untuk menunjukkan bahwa mereka adalah perwakilan dari televisi Jakarta. Menyandang status sebagai jurnalis resmi dari sebuah stasiun televisi nasional tentu kebanggaan tersendiri bagi para kontributor. Ketika menjalankan tugas jurnalistik, para kontributor berpikir mereka menjadi bagian dari borjuis media.

\section{KESIMPULAN DAN SARAN}

\section{Kesimpulan}

1. Telah terjadi komodifikasi kontributor dalam produksi berita televisi. Kapitalis media televisi memanfaatkan tenaga kontributor dengan membangun sistem produksi yang eksploitatif demi memperbesar keuntungan usaha atau mendapatkan nilai lebih (surplus value).

2. Kapitalis media televisi membangun sistem produksi absolut yang tidak memungkinkan kontributor memilih sistem produksi yang lain.

3. Kapitalis media televisi mempromosikan kesadaran palsu kepada kontributor dengan pemberian fasilitas peralatan kerja, seragam dan kartu identitas. Hal ini menyebabkan kontributor merasa menjadi bagian dari borjuis media.

\section{Saran}

1. Perlu dilakukan penelitian lanjutan untuk melihat dampak komodifikasi kontributor terhadap pemenuhan fungsi-fungsi ideal jurnalisme.

2. Perlu upaya intervensi dari pihak pemerintah untuk membenahi sistem industri penyiaran televisi sehingga tercipta iklim kerja yang adil.

3. Perlu upaya intervensi dari Dewan Pers dan IJTI untuk membantu menciptakan praktik jurnalistik yang bermartabat.

Ucapan Terima Kasih (Acknowledgement)

Terima kasih kepada Kementerian Ristek-Brin yang telah membiayai penelitian ini. Terima kasih kepada Dewan Pers dan Ikatan Jurnalis Televisi Indonesia yang telah membantu memberikan masukan dan tanggapan terhadap data penelitian ini.

\section{REFERENSI}

Armando, A. (2011). Televisi Jakarta di atas Indonesia: Kisah kegagalan sistem televisi berjaringan di Indonesia. Bentang.

Armando, A. (2016). Televisi Indonesia di bawah kapitalisme global. Buku Kompas.

Blumenthal, H.. Goodenough, O. (2006). This business of television: The standard guide to television industry. Billboard Books.

Creswell, J. W. (2007). Qualitative inquiry and research design: Choosing among five approaches 2 nd ed. Sage Publication.

Duilah, I. (2019, Februari 3). Upah rendah masih jadi ancaman jurnalis Indonesia. Aliansi Jurnalis Independen (AJI). https://aji.or.id/read/press-release/899/upah-rendah-masih-jadiancaman-jurnalis-indonesia.html. 
Doyle, G. (2006). Understanding media economics. Sage Publication.

Ibrahim, I. S., Akhmad, B. A., (2014). Komunikasi \& komodifikasi: Mengkaji media dan budaya dalam dinamika globalisasi. Pustaka Obor.

Kriyantono, R. (2020). Teknik praktis riset komunikasi kualitatif dan kuantitatif. Prenada Media.

Lestari, R. Sri., Suherdiana, D., Enjang, M. (2018). Etos kerja wartawan kontributor MNC Group tentang kebijakan redaksi terpadu. Jurnal Ilmu Jurnalistik, 3(1), 67-89.

Lukitawati, B. (2019). Faktor strukturisasi dalam komodifikasi berita kriminal begal motor di Depok pada media online. Jurnal Ilmiah Komunikasi, 178 - 186.

McQuails, D. (2011). Teori komunikasi massa. Salemba Humanika.

Moleong, L. J. (2018). metode penelitian kualitatif. Remaja Rosda Karya.

Mosco, V. (2009). The political economy of communication. Sage.

Nielsen. (2020, November 3). Belanja iklan ditutup dengan tren positif. Siaran Pers. https://www.nielsen.com/id/id/press-releases/2020/belanja-iklan-2019-ditutup-dengantren-positif/

Putri, C. A., Endang, A., Indasari, F. (2018). Komodifikasi pekerja di lembaga penyiaran publik $\begin{array}{llllll}\text { TVRI Bengkulu. Jurnal } & 49 .\end{array}$ https://doi.org/10.37676/professional.v5i2.965.

Santoso, D. H., Lestari, R. D., (2018). Legalitas stringer dan karya jurnalistik dalam media televisi. Jurnal Pekommas, 2(2), 115 - 124. https://dx.doi.org/10.30818/jpkm.2017.2020201.

Yoedtadi, M. G., Hapsari, Z. (2020). Pemanfaatan media sosial di televisi grup MNC. Jurnal Lontar. 8(1), 16 - 24. https://doi.org/10.30656/lontar.v8i1.1540.

Yoedtadi, M. G., Loisa, R., Sukendro, G. G., Oktavianti, R., Savitri, L. (2020). Tantangan jurnalisme damai di wilayah pasca konflik. Jurnal Penelitian Komunikasi dan Opini Publik. 24(1): 31 - 44. 